\title{
Avian injury assessment for the Deepwater Horizon oil spill
}

\author{
P. L. Tuttle • J. M. Hemming
}

Received: 16 October 2019 / Accepted: 17 October 2019

(C) This is a U.S. government work and not under copyright protection in the U.S.; foreign copyright protection may apply 2020

On April 20, 2010, the Deepwater Horizon (DWH) mobile drilling unit exploded, caught fire, and eventually sank in the Gulf of Mexico. Tragically, 11 workers were killed and 17 injured. The incident also resulted in the uncontrolled release of oil and natural gas into the Gulf of Mexico at a depth approximately 1 mi below the surface. The release continued for 87 days before the well was successfully closed. Estimates placed the amount of oil released at approximately 3.19 million barrels (134 million gallons). Cumulatively, more than $43,300 \mathrm{mi}^{2}$ of the Gulf of Mexico and more than $1300 \mathrm{mi}$ of shoreline were oiled.

As an oil pollution incident, the DWH oil spill was subject to the provisions of the Oil Pollution Act of 1990 (OPA). Under OPA, federal and state agencies with natural resource trust responsibilities (Trustees) are authorized to assess natural resource injuries resulting from the incident and work together to make the environment and public whole for those injuries. The goal of the Natural Resource Damage Assessment (NRDA) process is to (1) assess the natural resource injuries resulting from the DWH oil pollution incident and then (2) develop and implement a restoration plan to restore the injuries to compensate the public for the loss of natural resources as a result of the spill.

As the enormity of the DWH oil spill became apparent in early May, 2010, the US Fish and Wildlife Service

P. L. Tuttle $(\bowtie) \cdot$ J. M. Hemming

US Fish and Wildlife Service, 341 Greeno Rd., Suite A, Fairhope, AL 36532, USA

e-mail: pete_tuttle@fws.gov
(FWS) convened a team of experts to design an approach to assess potential injuries to resources for which the FWS has trust responsibilities. Chief among these potentially injured resources were birds. The initial steps included the evaluation of pathways of exposure, mechanisms of injury, habitats at risk, and bird species at risk. The team identified three primary models to estimate avian injuries, the Shoreline Deposition Model, the Live Oiled Bird Model, and a Pelagic Bird Exposure Model. The team also identified a series of field studies to inform the model parameters and to reduce uncertainty in model estimates.

\section{Shoreline deposition model}

The Shoreline Deposition Model (SDM) is a variation of the Beached Bird Model, which has been used to estimate avian mortality in several prior oil spills, such as Apex Houston (Page et al. 1990), Exxon Valdez (Ford et al. 1996), New Carissa (2001), and Cosco Busan (Ford et al. 2009). The SDM was identified as the appropriate tool to estimate spill-related mortality on walkable shorelines for the DWH oil spill. Principle inputs to the SDM include the number of carcass found on shorelines, human effort dedicated to finding carcasses (search effort), the probability of a bird that dies on the water being deposited on a shoreline (carcass drift), the length of time that carcasses remain on shorelines (carcass persistence), carcass findability (carcass detection), and natural rate of mortality (background 
mortality). Several studies were conducted to generate the required data.

Systematic surveys to assess carcass deposition rates were initiated in Mississippi, Alabama, and the Florida panhandle on May 17, 2010, and in Louisiana and Texas on May 24, 2010. Due to uncertainties of the eventual geographic extent of the spill impact, and estimated scenarios that the impacts could spread throughout the Gulf and potentially enter the Atlantic Ocean via the loop current, beach surveys extended from South Texas to the Florida Keys along the Gulf coast and the Atlantic coast of Southeast Florida. The geographic extent of the surveys was reduced as the extent of the spill was better understood when the flow from the well was controlled and eventually stopped. Surveys were continued through September 2010. Although NRDA staff coordinated closely with Wildlife Operations personnel operating under the Unified Command to keep NRDA search segments separate, public and political pressures demanded the rapid recovery of bird carcasses from designated NRDA survey transects. Therefore, birds recovered by non-NRDA personnel (Wildlife Operations, Law Enforcement, or others) were included in recovery data for the SDM. Studies to assess searcher efficiency and carcass persistence in marshes were conducted in late summer, 2010. The carcass drift study was conducted in summer, 2011.

As the spill progressed, marsh habitats in Louisiana were repeatedly oiled and Wildlife Operations personnel collected large numbers of dead and impaired birds from marsh habitats. Shoreline surveys conducted as part of the SDM were specific to walkable shorelines. Marsh edges were not systematically surveys by NRDA field crews. To appropriately consider and model mortality in marshes, Wildlife Operations records were compiled to evaluate search effort and carcass recoveries along marsh edges for use in the SDM.

In this special edition, Amend et al. review the general construct of the SDM and evaluate the sensitivities of model input data. Himes Boor and Ford (2019) and Martin et al. (2019) provide two methodologies to estimate the probability of whether birds dying on the water would be deposited on shorelines of the northern Gulf of Mexico. Zimmerman et al. (2019) describe and provide the results of the Searcher Efficiency Study. Varela and Zimmerman (2019) describe and provide the results of the Carcass Persistence Study.

\section{Live oiled bird model}

Our second bird injury model, the Live Oiled Bird Model (LOBM), was developed to estimate mortality of coastal birds that were observed oiled and alive but were not sufficiently impaired to enable their capture and rehabilitation. A similar approach was used to estimate bird injury in the M/T Athos 1 oil spill in New Jersey (NOAA et al. 2009). Data required for the LOBM included (1) the numbers of birds occurring in areas affected by the oil spill (abundance), (2) the incidence and degree to which birds were oiled (oiling rates), and (3) the fate of oiled birds (i.e., the likelihood a bird would die due to oil exposure). The Trustees implemented several studies to generate these data for dominant bird groups, or guilds, affected by the DWH oil spill.

Pursuant to NRDA regulations, the Trustees are prohibited from redundant injury documentation for natural resource damages. Accordingly, the Trustees recognized the need to ensure that the LOBM and SDM did not estimate mortality for the same birds. To avoid redundant injury documentation, the SDM was used to capture spill-related mortality occurring before October 1, 2010, and the LOBM was used to capture mortality occurring on or after October 1, 2010. However, the Trustees recognize that some birds that were oiled prior to October 1 may have died after October 1 .

Low-level aerial surveys were identified as the most efficient method of estimating coastal bird abundance across the potential geographic extent of the spill. These survey methods that were developed for assessing bird abundance in oil spills along the west coast were adapted in the northern Gulf of Mexico. Aerial surveys for the DWH NRDA were initiated on May 6, 2010. Surveys continued monthly until March, 2011. The survey area initially included shorelines and bays from Corpus Christi, Texas, to the Florida Keys and the Dry Tortuga islands. Low-level aerial surveys included shoreline surveys, zigzag transects between the shore and barrier islands (or out to $5 \mathrm{mi}$, in the absence of barrier islands), and offshore transects extending about 100 miles seaward. Again, the geographic extent of the surveys was reduced as the extent of the spill was better understood when the flow from the well was controlled and eventually stopped.

Oiling rates for key at-risk bird groups were determined through a series of field studies including the Colonial Waterbird Study for colonial nesting species (DWH Bird Technical Workgroup 2010a), the Non- 
Breeding Shorebird Study for shorebirds wintering in the Gulf of Mexico (DWH Bird Technical Workgroup 2010b), the Waterfowl Study for waterfowl (DWH Bird Technical Workgroup 2010c), and the Wintering OpenWater Waterbird Study for species that winter in openwater nearshore areas (DWH Bird Technical Workgroup 2010d). The plans and technical reports for these field studies may be found in the administrative record for the Deepwater Horizon Oil Spill NRDA at https://www.doi. gov/deepwaterhorizon/adminrecord. As part of each of these studies, birds were observed to evaluate the occurrence and severity of external oiling. Observed birds were recorded as follows: (1) not visibly oiled, (2) trace oiling (less than 5\% of the body surface), (3) light oiling (5 to 20\%), (4) moderate oiling (21 to 40\%), or (5) heavy oiling (greater than $40 \%$ ).

The Trustees also convened a panel of experts to estimate the probability of mortality for birds externally exposed to oil using available literature, case-specific toxicity information, and expert opinion based on extensive experience. The panel estimated the probability of mortality for dominant bird guilds for each of the four external oiling categories. The findings of this review are presented in Dobbs et al. (2015). Mortality estimates were slightly modified based on the results of avian toxicity studies (Ziccardi 2015). Both reports may be found in the administrative record for the Deepwater Horizon Oil Spill NRDA at https://www.doi. gov/deepwaterhorizon/adminrecord.

In this special edition, Paruk et al. review the findings of the Wintering Open-water Waterbird Study.

\section{Pelagic bird exposure model}

The Trustees learned from the carcass drift evaluation that birds that died more than $40 \mathrm{~km}$ from shore (offshore) would never reach the shore and would not be accounted for by the results of the SDM. Therefore, the Trustees used an Offshore Exposure Model to estimate mortality of birds in offshore areas (IEc 2015). This model used bird density, exposure estimates, and the fate of oiled birds to quantify bird mortality. To estimate bird densities in offshore areas, ship-based surveys were conducted from July 2010 to July 2011 (Pelagic Bird Study). The number of birds potentially affected by oil exposure was determined by multiplying the density of birds in offshore areas by the surface area of the Gulf of Mexico that was covered by oil (footprint). The Trustees assumed that all birds occurring in the footprint would be exposed to oil over the 87day course of these calculations. The Trustees distributed the number of estimated oiled birds evenly across the four oiling categories noted for the LOBM and applied ranges of mortality rates corresponding to each oiling category. Dobbs et al. (2015) and Ziccardi (2015) were again used to estimate mortality of birds within each oiling category to generate the offshore mortality estimate.

In this special edition, Haney et al. review the findings of the Pelagic Bird Study.

The overall estimate of injury to birds, as well as lessons learned, as the result of the DWH oil spill was described in the Deepwater Horizon Oil Spill Final Programmatic Damage Assessment and Restoration Plan and Final Programmatic Environmental Impact Statement (DWH NRDA Trustees 2016).

\section{References}

Dobbs, R., Ford, S., Fry, M., Hunter, C., Tseng, F., and Ziccardi, M. 2015.Draft final: Literature-based fate estimate of birds exposed to the Deepwater Horizon/Mississippi Canyon oil spill: Panel summary DWH Bird Technical Work Group. 2010. Work Plan for Estimating Oiling and Mortality of Breeding Colonial Waterbirds from the Deepwater Horizon (MC 252) Oil Spill (Bird Study \#4).

DWH Bird Technical Work Group. (2010a). Work Plan for Estimating Oiling and Mortality of Breeding Colonial Waterbirds from the Deepwater Horizon (MC 252) Oil Spill (Bird Study \#4). Available at: https://www.doi. gov/deepwaterhorizon/adminrecord.

DWH Bird Technical Work Group. (2010b). Work Plan for Estimating Shorebird Oiling and Mortality Deepwater Horizon (Mississippi Canyon 252) Oil Spill Bird Study \#5. Available at: https://www.doi.gov/deepwaterhorizon/adminrecord.

DWH Bird Technical Work Group. (2010c). Work Plan For Estimating Wintering Waterfowl Oiling and Mortality (Bird Study \#10). Available at: https://www.doi. gov/deepwaterhorizon/adminrecord.

DWH Bird Technical Work Group. (2010d). Work Plan For Determining Oiling Rates and Mortality of Wintering OpenWater Waterbirds From The Deepwater Horizon (Mississippi Canyon 252) Oil Spill (Bird Study \#12). Available at: https://www.doi.gov/deepwaterhorizon/adminrecord.

DWH NRDA Trustees. (2016). Deepwater Horizon Oil Spill Final Programmatic Damage Assessment and Restoration Plan and Final Programmatic Environmental Impact Statement. Available at: https://www.doi.gov/deepwaterhorizon/adminrecord.

Ford, R. G., Bonnell, M. L., Varoujean, D. H., Page, G. W., Carter, H. R., Sharp, B. E., Heinemann, D., \& Casey, J. L. (1996). Total direct mortality of seabirds from the Exxon Valdez oil 
spill. In American Fisheries Society Symposium, 18, 684711.

Ford, R. G, G. K.H Boor, and J. C Ward. (2001). "Seabird mortality resulting from the $\mathrm{M} / \mathrm{V}$ New Carissa oil spill incident February and March 1999”. Final Report by RG Ford Consulting Company to US Fish and Wildlife Service.

Ford, R. G., J. L. Casey, and W. A. Williams. (2009). “Acute seabird and waterfowl mortality resulting from the $\mathrm{M} / \mathrm{V}$ Cosco Busan oil spill, November 7, 2007'. Final Report prepared for: California Department of Fish and Game, Office of Spill Prevention and Response Final Report.

Himes Boor, G.K., Ford, R.G. (2019). Using a mark-recapture model to estimate beaching probability of seabirds killed in nearshore waters during the Deepwater Horizon oil spill. Environ Monit Assess 191, 813. https://doi.org/10.1007 /s10661-019-7919-9.

IEc (Industrial Economics, Inc.). (2015). Estimating the offshore mortality of birds killed by DWH oil. DWH oil spill NRDA technical report. Available at: https://www.doi. gov/deepwaterhorizon/adminrecord.

Martin, N., Varela, V.W., Dwyer, F.J. et al. (2019). Evaluation of the fate of carcasses and dummies deployed in nearshore and offshore waters of the northern Gulf of Mexico. Environ Monit Assess 191, 814. https://doi.org/10.1007/s10661-0197923-0.

NOAA, USFWS, New Jersey Department of Environmental Protection, Delaware Department of Natural Resources and Environmental Control, Pennsylvania Department of
Conservation and Natural Resources, Pennsylvania Department of Environmental Protection, Pennsylvania Fish and Boat Commission, and Pennsylvania Game Commission. (2009). Final restoration plan and environmental assessment for the November 26, 2004, M/T Athos I Oil Spill on the Delaware River near the Citgo Refinery in Paulsboro, New Jersey.

Page, G. W., Carter, H. R., \& Ford, R. G. (1990). Numbers of seabirds killed or debilitated in the 1986 Apex Houston oil spill in Central California. Studies in Avian Biology, 14, 164 174.

Varela, V.W., Zimmerman, G.S. (2019). Persistence of avian carcasses on sandy beaches and marsh edges in the northern Gulf of Mexico. Environ Monit Assess 191, 815. https://doi. org/10.1007/s10661-019-7920-3.

Ziccardi, M. (2015). Expert assistance - Deepwater Horizon oil spill bird injury. Davis, CA. DWH Birds NRDA Technical Working Group Report. Available at: https://www.doi. gov/deepwaterhorizon/adminrecord.

Zimmerman, G.S., Varela, V.W., and Yee, J.L. (2019). Detection probabilities of bird carcasses along sandy beaches and marsh edges in the northern Gulf of Mexico. Environ Monit Assess 191, 816. https://doi.org/10.1007/s10661-019-7924-z.

Publisher's note Springer Nature remains neutral with regard to jurisdictional claims in published maps and institutional affiliations. 